\title{
74 ネマチック液晶セルの透過光特性について（III）
}

\section{高橋明遥石坂武坪井常世仁平幸治 \\ (日本工業大学) (明治大学)}

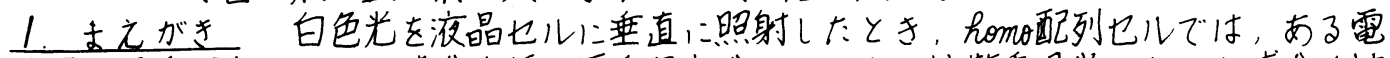
界簕用で正透過光のような成分（仮に正透過光分とする）と拡散透過光のような成分（拡

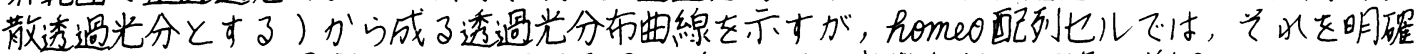
に判别する:とは图難であり，印加電界の堌加と共に光散乱性が次第に增加していく:

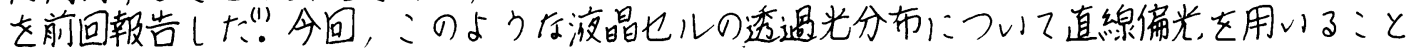
により、さらに両者の遗いを明らか心にた。

2. 实駼方法ゴニオフォトメーターの入射光側三偏光子を橧入し，光水を10每に

○゚ 180まで回転し，光のおのおのについて透過光分布曲線を求めた。光の際，測光面と偏

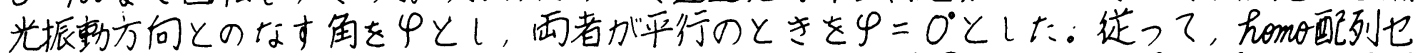

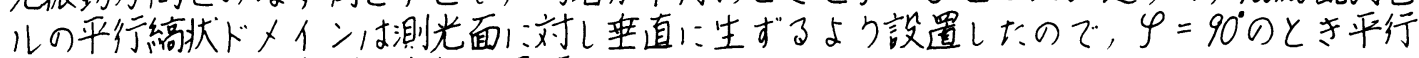
縞状ドメインと偏光振锄方向、平行になる。

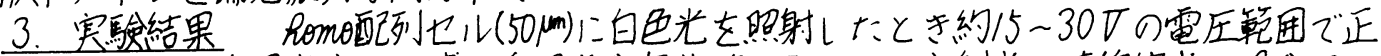
透過光分と㕬散透過光分から成了透過光分布曲線を示すが，入射光が道線偏光の堨合ほほ 同梯の電压䡉围で正透過光分乙㧓散透過光分：偏光振動方向依存性のある透過光分布曲線

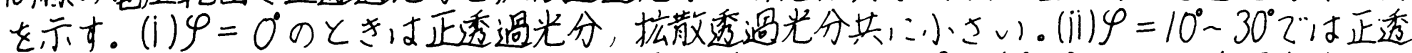
過光分士急激に增加儿嫲散透過光分毛次第一增加才る。(jii) $\varphi=40^{\circ} \sim 90^{\circ}$ では正透過光分はほ

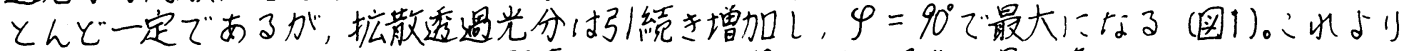
拡散透過光分は $\varphi=20^{\circ}$ 付近から顕著、ない始め $\varphi=90^{\circ}$ の場合に最も多くなる:とがわが 白色光で見られ大㧓散透過光分はドメインと平行な振動方向を持つ偏光成分の影譩による

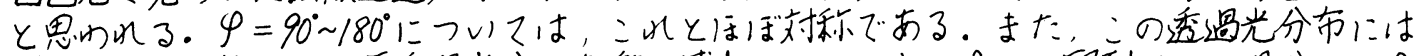

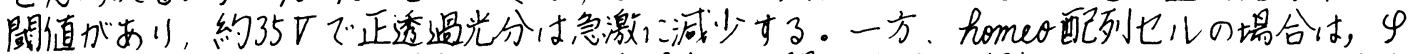
の变化以詨しても，正透過光分と拡散透過光分の間:明䍜な判别をつけにくい:とは白色

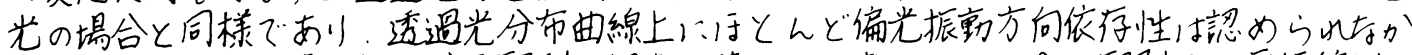
った。:れらの相違は初期分子配列の相違、基亏くと考之られ，homo配列では平行縞状ド

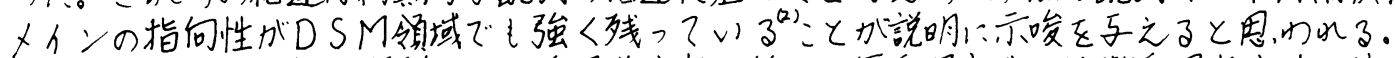

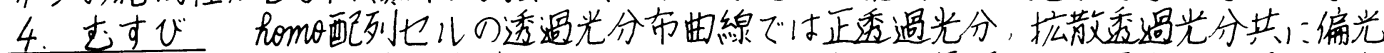
振動方向依存性があ小，平行縞状ドメインと偏光振敦方向が平行のとき禹者共:最大、栾

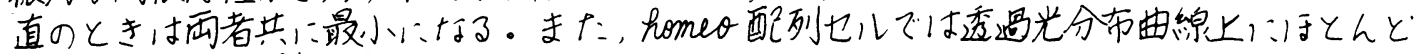
偏光振動方向依存性は認めら几的か。大

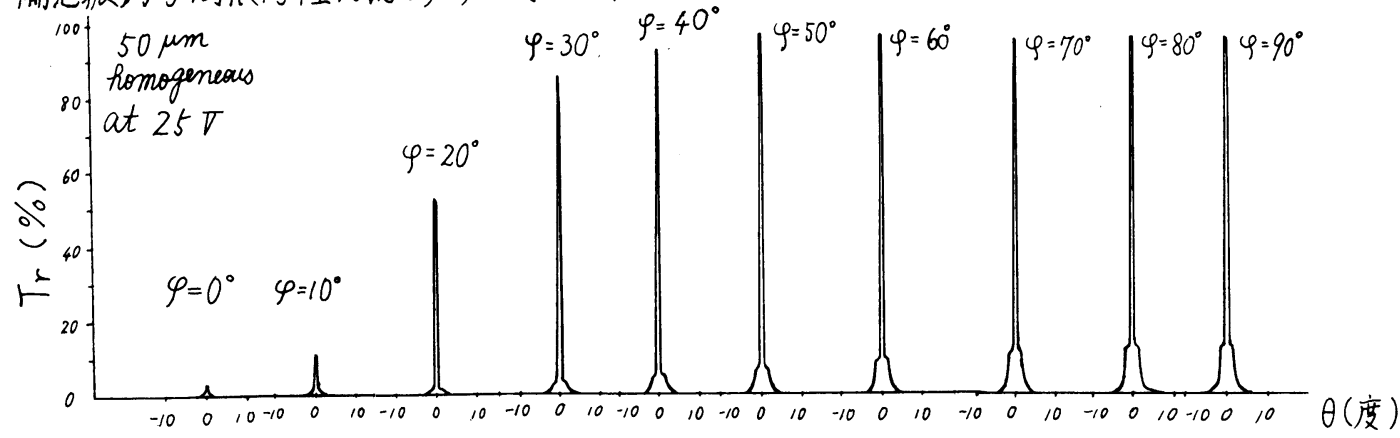

参考文献(1)高橋他: 本会昭和5/講演論文集102, (2)松本他: 忘物誌45(1976)763 